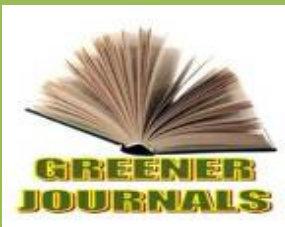

\title{
Impacts of Erotic Weather Patterns as a Result of Climate Change and Variability on Food Crop Productivity and Food Security in Zimbabwe's Arid Regions of Matabeleland; A Case of Siabuwa Communal Area in Binga District
}

\section{Chisango Future Fortune T and Maposa Angela*}

\author{
${ }^{1}$ senior lecturer faculty of agriculture, Zimbabwe open university, Zimbabwe. \\ ${ }^{2}$ senior lecturer faculty of arts and education, Zimbabwe open university, Zimbabwe. \\ Email: fchisango5@yahoo.com
}

\section{ARTICLE INFO}

Article No.: 030316054

DOI: 10.15580/GJAS.2016.3.030316054

Submitted: 03/03/2016

Accepted: 11/03/2016

Published: 28/03/2016

${ }^{*}$ Corresponding Author

Maposa Angela

E-mail: angelamaposa@gmail.

com

\section{Keywords:}

Climate change; Climate

variability; Food insecurity;

Livelihood shocks; Adaptation;

Drought resistant crops
This article explores the impact of climate change and variability on food crop productivity in Siabuwa area of Binga district in Matabeleland North Region. The study further examined community based adaptation and mitigation strategies devised by local farmers to cushion the catastrophic effects of climatic transformations. The sustainability of such strategies was also interrogated in the article. The study made use of qualitative methodologies where primary data was generated from a sample of 100 households drawn from a population of 400 family units. Agricultural experts and other stakeholders such as Nongovernmental organizations operating in the district produced records which were critical in the compilation of secondary data. The research used questionnaires and interviews to solicit information and obtain a broader understanding of climate change and livelihood issues from key informants and ascertain how knowledgeable people in the study area were about shocks resulting from climatic modifications and finally establish the adaptation and mitigation strategies devised by farmers to deal with the shocks emanating from such transformations. It was established that some of effects of climatic inconsistencies felt by communal farmers in Siabuwa area included total crop failure, death of livestock and over exploitation of natural resources, all of which have led to declining agricultural productivity and massive devastation of the natural resources base hence plunging local communities into persistent food insecurity and miserable poverty. Findings in the study however established that local communities have not been submissive to the catastrophic effects of climate change and variability, as they have equally responded by adopting various adaptation and mitigation strategies both individually and collectively. The study concluded that widespread poverty and food insecurity in arid regions of Zimbabwe are directly linked to climatic transformations as it has been established that poor agricultural productivity is aggravated by climate change and variability. 


\section{INTRODUCTION}

Yields of major food crops have been declining over the past decade, threatening food security in most districts of Matabeleland North region, with Binga being the most severely affected district. The proneness of the area to incessant droughts characterized by heat waves has subjected agriculture to great risk and uncertainty, impacting negatively on food crop productivity hence exposing households to severe food insecurity, famine and abject poverty. Farmers have little knowledge about the phenomenal occurrences resulting from climate change and variability, and due to their traditional beliefs they have little understanding and appreciation of the impact of climatic transformations on their farming activities especially declining trends of crop productivity. It is therefore against this backdrop that the study sought to divulge the possible impacts of erotic weather patterns as an attribute of climate change and variability on food crop productivity in arid regions of the country.

\section{BACKGROUND OF THE STUDY}

Climate change is a significant and lasting change in statistical distribution of weather patterns over periods ranging from decades to millions of years and may be a change in average weather conditions (Unganai, 1996). Mahiya \& Gukurume, (2014) however cited that climate change is about long term changes in weather conditions that differ significantly from previous averages. They noted that it manifests itself in droughts and floods that are caused by global warming or increases in temperatures due to greenhouse gas emissions. The emissions include carbon dioxide, methane and nitrous oxide resulting from human activities such as combustion of fossil fuels, industrial processes and deforestation. The inverse relationship between global climate change and variability, and agricultural productivity is significant but has been greatly underestimated in many developing African nations.

Slater, Peskett, Lundi\& Brown (2007) in Gukurume, (2014) cited that agriculture is the backbone of Southern Africa's economies and at least $65 \%$ of the region's citizens live in rural areas and rely on rain fed agriculture. However, the sector's performance is adversely affected by climate change. For example, it was expected that drought as a result of climate change would reduce rain fed crop yield by as much as $50 \%$ in some parts of Zimbabwe (Jain, 2007; Mika, 2010). Climate change can therefore contribute to food insecurity and drive the region's subsistence farmers to adopt unsustainable coping strategies such as overrelying on natural resources for survival hence leading to increased deforestation, biodiversity loss and increased human wildlife conflicts. Rosenzweig \& Parry, (1994) cited thatdespite technological advances in plant breeding, fertilizers and irrigation systems; climate remains a key factor and variable determining agricultural production. Maize which is ranked the main staple food crop followed by wheat and sorghum, occupies about half of the agricultural land in Zimbabwe (Chasi \& Shamudzarira, 1992). The crop is however greatly affected by ambient temperatures, scarce precipitation as well as high frequencies of heat waves and droughts which are regarded significant determinants influencing its productivity in Southern Africa. And as Zimbabwe's largest population is dependent on agriculture for food, income and livelihood systems it is paramount that adaptation and mitigation strategies to climate change and variability need serious attention from all stakeholders.

Due to declining trends in food crop production, the problem of food insecurity has become more intensely pronounced in recent years in the country's rural communities with the threat of posing, to a greater magnitude catastrophic disasters on the poor populations, who happen to be the majority in the African continent. Impacts of climate change and variability do not spare ecosystems and biodiversity as they lead to massive degradation of natural environments; considered a buffer to harsh elements such as heat waves and excessive destructive winds.

Unpredictable rainfall patterns which subject farmers to poor planning are also assumed to be a result of climate change. Climate change is thus projected to increase the intensity and severity of heat waves, droughts and floods as it is usually associated with cyclones, which impact negatively on both commercial and subsistence agricultural activities in Zimbabwe, hence assumed that crop production will be seriously affected with yields drastically falling in most parts of the country. Two scenarios leading to yield reduction as a result of climate change have been observed in the country's agricultural sector namely; Late start of the rain season and premature or early termination of the season, leading either to low yields or total crop failure in extreme cases. The later being a common scenario in Siabuwa Communal Area of Binga District where incessant total crop failures have been recorded yearly for the past decade. Additional pressure on the land resources has also emanated from the population expansion as a result of retrenchments and displacement of mine workers from Wange Colliery and Kamativi mines who have been forced to take farming as the only option to eke a living after being subjected to miserable poverty.

Thus, with the vagaries of climate change already visible, considerable uncertainty surrounds the agricultural sector in many rural communities in Zimbabwe. More so, of note is the fact that due to the impact of climate change food security in marginalized areas may diminish and expose many people to hunger and famine. The need to sustainably increase agricultural productivity and to provide economically viable livelihood options for the vulnerable rural communities has therefore motivated this study which 
sought to explore the impact of climate change and variability on rural peasantry agriculture and the adaptation strategies devised by the local farmers to cushion the shocks resulting from the natural phenomenon. The study assessed vulnerability of the country's arid regions interns of food security and livelihood systems, but with particular reference to Binga, one of the so called marginalized districts in Zimbabwe.

\subsection{Statement of the problem}

Yields of major food crops have been declining over the past decade, threatening food security in Binga district. The proneness of the area to incessant droughts characterized by heat waves has subjected agriculture to greater risk and uncertainty, impacting negatively on food crop productivity hence exposing households to severe food insecurity, famine and abject poverty. Farmers have little knowledge about the phenomenal occurrences which are a result of climate change and variability, and due to their traditional beliefs this is just a natural phenomenon which can terminate with time, as they have little understanding and appreciation of climatic modifications and their negative impacts on farming activities especially declining trends of crop productivity and exposure of livestock to catastrophic shocks. It is therefore against this backdrop that the study sought to divulge the possible impacts of erotic rains and droughts as attributes of climate change and variability on food crop productivity and critical deficits experienced in arid regions of the country. The study focused on investigating impacts of climate change and variability on agricultural activities of the subsistence rural farmers as well as establishing the adaptation strategies being devised to cope with the catastrophic effects of such climatic modifications, by communities in Binga district; Matabeleland North Region.

\subsection{Research Objectives}

The main objective of the research was to assess impacts of unreliable weather patterns as a result of climate change on food security and livelihood systems of communal farmers in arid regions of Zimbabwe, but with particular reference to Siabuwa area in Binga District. However the specific objectives were;

- To establish whether the inhabitants of the study area were knowledgeable about climate change and its possible catastrophic effects on agricultural productivity.

- Establish whether climate change and variability are a causation of widespread poverty and famine affecting communities in the district

- To identify adaptation and mitigation strategies adopted by local communities to cushion the impact of climatic transformations

\section{RESEARCH METHODOLOGY}

The study made use of qualitative methodologies where primary data was generated from a sample of 100 households drawn from a population of 400 family units in Siabuwa area of Binga district. Agricultural experts and other stakeholders such as Nongovernmental organizations operating in the district produced records which were critical in the compilation of secondary data. The research used questionnaires and interviews to solicit information and obtain a broader understanding of climate change and livelihood issues from key informants and ascertain how knowledgeable people in the study area were about shocks resulting from climatic modifications and establish the adaptation and mitigation strategies devised by farmers to deal with the shocks. Data obtained were subjected to descriptive statistics where tables, frequency counts, mean and percentages were predominantly used to present findings.

\section{RESULTS AND DISCUSSION}

\section{Crop and livestock production}

Table 1: Crops grown in order of priority

\begin{tabular}{|l|l|}
\hline CROP & FREQUENCY \\
\hline maize & 70 \\
\hline cotton & 15 \\
\hline sorghum & 12 \\
\hline Pearl-millet & 2 \\
\hline Ground nuts & 1 \\
\hline
\end{tabular}

Farmers in Siabuwa area, Binga district consider maize to be their major crop as indicated by $70 \%$ response rate of the participants. However it was observed that though rated highly the crop has been failing to yield above average total physical product/hectare due to various reasons, but with changing weather patterns characterized by incessant droughts and excessive heat being cited as the major contributory variable. Cotton 
which is rated second with $15 \%$ was preferred for income generation but unfavourable prices averaging 12 cents/kg have forced farmers to operate below the break-even point hence compelling them to drop the venture. Poor road network has also been cited as a deterrent obstacle which incapacitates potential buyers from accessing local sales depots in the producing zones; as witnessed at Siabuwa Service centre where piles of bales from the previous seasons were scattered in the depot uncollected. Though small grains were regarded strategic in cushioning the impact of droughts and food deficits the majority of farmers registered discontent in the crops due to bad taste when used to prepare thick porridge/sadza which constitutes the main diet in the area. Some farmers however cited intensive labour associated with the production of the crops and depressed yields per given unit area as the main deterrent factors. Groundnuts was regarded an insignificant, minor crop and mainly a preserve for women as its uses were only restricted to extraction of edible oils.

Table 2: Livestock kept in order of priority

\begin{tabular}{|l|l|}
\hline LIVESTOCK & FREQUENCY \\
\hline cattle & 40 \\
\hline goats & 20 \\
\hline sheep & 15 \\
\hline Donkeys & 10 \\
\hline Indigenous chickens & 10 \\
\hline Genie-fowl & 5 \\
\hline
\end{tabular}

Farming households in Siabuwa area, regard cattle highly as $40 \%$ of the participants indicated that the significance of cattle in determining status of a family and being regarded as a bank was a traditional phenomenon with strong roots imbedded in the African culture hence needed to be preserved. Farmers cited that apart from the broad-spectrum significance such as provision of meat, milk organic fertilizers and draught power cattle are a buffer to catastrophic effects of natural shocks such as droughts which can be a result of climate variability through facilitating barter trade where they can be exchanged for scarce commodities such as food resources. Though rated highly it was observed that cattle in Siabuwa are heavily exposed to devastating effects of drought which has badly hit the area. Fear of the risk of losing the whole herds due to excessive drying of pastures and water sources is pushing farmers to dispose their livestock at exploitive prices with an LU livestock unity (animal with a live weight of $500 \mathrm{~kg}$ ) fetching US 180 on average or being bartered with 20 buckets of shelled maize. On small livestock the majority of farmers identified cash as the key function provided by such type of livestock. Participants alluded to the fact that since small livestock does not fetch as much grain when bartering as cattle, they were critical in that they represented small bundles of cash and served as a buffer against challenges of liquidity crisis affecting most rural communities in the district. It was indicated that cash from livestock was primarily spent on food and payment of tuition fees, health care and farming inputs. The second most important function was food in the form of meat and milk. It was therefore established that livestock generally contribute directly to food security, and the general welfare of rural communities.

\section{Average Rainfall as a determinant agricultural productivity in the study area}

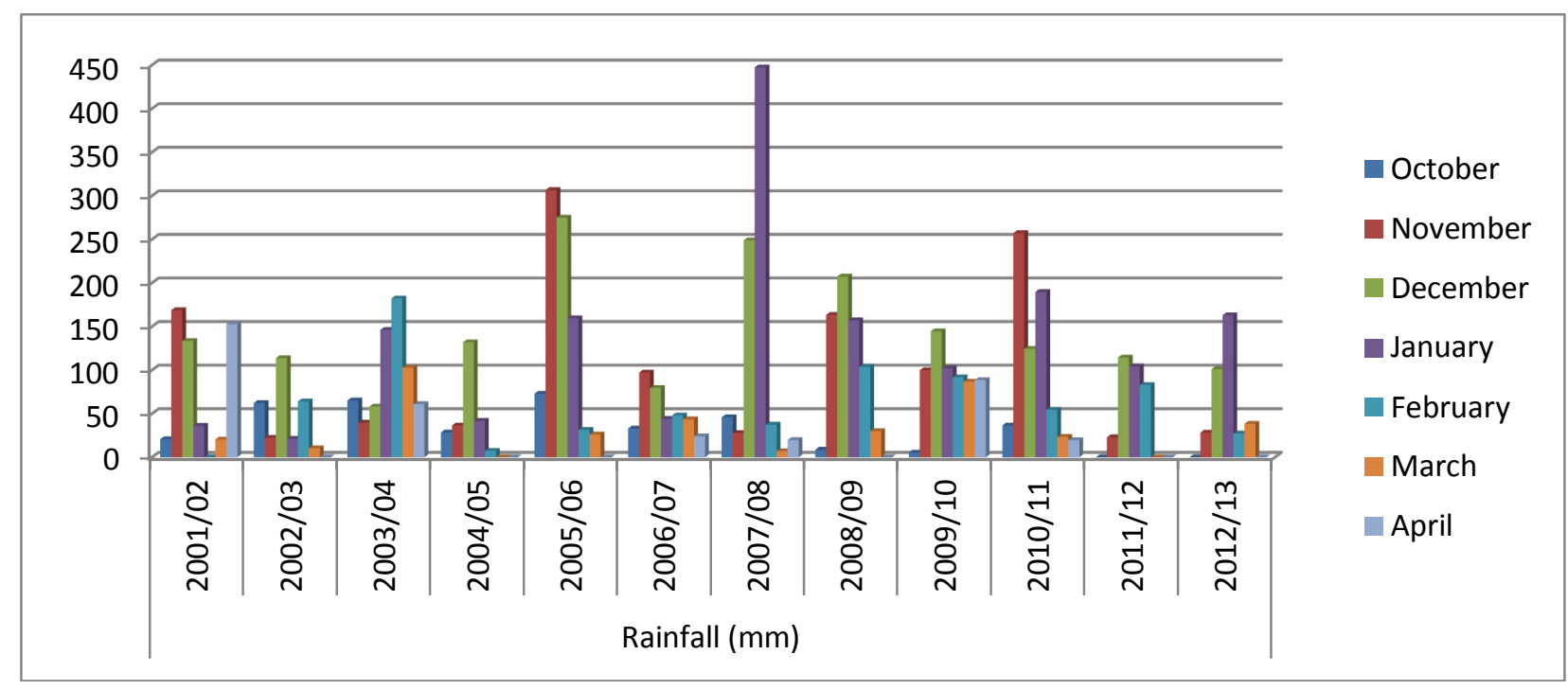


Comparison of average yields and season length

\begin{tabular}{|l|l|l|}
\hline Year & Average Yield(tons/ha) & Season Length(days) \\
\hline $2002-2003$ & 0.3 & 26 \\
\hline $2003-2004$ & 0.5 & 133 \\
\hline $2004-2005$ & 0.42 & 53 \\
\hline $2005-2006$ & 0.65 & 147 \\
\hline $2006-2007$ & 0.23 & 41 \\
\hline $2007-2008$ & 0.34 & 97 \\
\hline $2008-2009$ & 0.6 & 154 \\
\hline $2009-2010$ & 0.57 & 162 \\
\hline $2010-2011$ & 0.51 & 127 \\
\hline $2011-2012$ & 0.43 & 89 \\
\hline $2012-2013$ & 0.25 & 77 \\
\hline
\end{tabular}

Figure 4.1 and From Table 4.3 above illustrate the rainfall trends in Binga district for the years 2002-2013; it is generally indicated that though the amount of rainfall received may be sufficient for low yielding short season maize varieties and most of the small grains, its distribution is however too erotic to sustain crop growth. Seasons are normally characterized by false starts at the onset, prolonged dry spells and heavy falls at the end where large amounts of rainfall can fall within a short period of about a month in a season resulting in heavy runoff and water logging in poorly drained soils. Unpredictable rainfall patterns subject farmers to poor planning, high risks and uncertainty which affect their activities hence reduce yields significantly. Most of the participants therefore indicated that rainfall distribution and amount were the major agricultural production constraints resulting in a sharp decline in land utilization and crop productivity.

Adopted community based coping strategies for impacts of climate variability in Binga District Bartering and sale of livestock

For survival villagers had no but to engage in barter trade. The only merchandise at their disposal was in the form of livestock which they exchanged for bags of maize. Even if they are short changed the poor farmers let their cattle go out of desperation. The researchers noticed the tense atmosphere of "do or die", and extreme anxiety which left farmers with no better option but being highly exposed to exploitative unscrupulous traders at the point of sale. During the fieldwork it was also established that the livestock that would have survived the drought are sold for a song (meager value), as desperate villagers fear the uncertainty of prospects of having better seasons ahead, and the risk of having their entire herds being wiped off by drought.

\section{Forced marriages}

Culturally the communities still believe that the girl child should be groomed for marriage. This means that education of the girl child is regarded less important. Though from the face to face interviews, it emerged that there were forced marriages. It was established that starving families married off their girl children to relatively well-up villagers and those were marked by polygamous families. It was assumed that only rich men had the capacity to look after more than one wife and many children. The poor villagers in the drought stricken zones have gone to the extent of marrying off their daughters to the outsiders who had surplus maize reserves.

\section{The role of nongovernmental organizations}

Non-governmental organizations have penetrated the district and give aid in the form of bicycles for learners whose homes are far away from schools and food hand outs for hungry families. It was however observed that such assistance is not in any way resolving the predicament of the troubled Siabuwa area. The households are not being empowered in anyway because as the saying goes "Give them fish, you bring an end to their hunger, but teach them how to fish and you empower them". It is therefore imperative that Non Governmental Organizations should establish projects which will enable the disadvantaged communities in the district to fend for themselves and shun the dependence syndrome which has become a cancer as people now rely on the benevolence of NGOs hence even the youths, in their prime productive ages are reluctant to work and fend for themselves.

\section{The role of the Government of Zimbabwe (GoZ)}

Alongside the NGOs the government of Zimbabwe through its MOUS Memorandum of Understanding is partnering with humanitarian organizations such as USAID, World Vision, Save the Children (UK), the WFP World Food Program and FAO Food Agricultural Organization to mobilize food resources from benevolent well-wishers world over in an effort to fight hunger and starvation in the district. To cushion critical food deficits the involved stakeholders provide food handouts to 
families and the rations are based on sizes of households. The study however established that as many households were getting far much less than a month's supply of food from their fields even if they make frantic efforts to cultivate on the fertile alluvial soils on river banks, there was need to heavily depend on food hand outs from donors.

\section{Hunting and gathering of wild fruits}

To ease hunger and starvation, some respondents retorted that they resorted to gathering of wild fruits, berries, vegetables and honey. Fishing which could be an integral facet in the generation of income for the local communities is poorly organized and is dominated by foreign companies from better off regions, owned by giant politicians who have become big business tycoons who amass wealth on the expense of developing their constituencies.

\section{Remittances}

For the few with relatives employed elsewhere particularly the country's urban centers and the Diaspora, remittances have also been cited as a major source of cash inflows for some households.

\section{CONCLUSIONS AND RECOMMENDATION}

\subsection{Conclusions}

The Zimbabwe economy is based on agriculture which in turn depends heavily on the weather patterns. The adverse impacts of climate change therefore present some of the biggest challenges currently threatening the country's agricultural sector and food security. There is extreme urgency from stakeholders in taking real action to mitigate the negative impacts of climate change. The lack of adaptive capacity by most of the vulnerable African populations means if appropriate measures are not put in place the lives of most people will be at risk as hunger and poverty may lead to disease outbreaks which will eventually lead to termination of innocent lives. The government and its partners should be urged to accelerate the awareness campaigns to educate its citizenry of the negative impacts of climate change so that integrated mitigation strategies which encompass community based indigenous technologies can employed. Climate change information should be packed in simple, understandable languages and disseminated widely across all districts and cascaded to all wards in the country's marginalized regions.

\subsection{Recommendations}

The study identified a number of challenges with great potential of posing serious threats to food security in the country's marginalized regions as a result of climate change and variability. In view of such challenges the study recommended the following:

- Mobilization of enough food resources and build the country's grain reserves/stocks to cushion deficits which result from incessant droughts, an attribute of climate change and variability.

- Mobilization of machinery and resources to resuscitate irrigation systems and projects as rain fed agriculture is becoming vulnerable to unpredictable weather conditions resulting from climate variability.

- Fishing and hunting communities need to participate in policy making and consultative forums so that their views are captured and, be co-opted in to policy making frameworks. Funds generated from fishing and hunting should be channeled towards developmental projects at ward level to sustain people's livelihoods.

- Government has to be gender sensitive, hence promote the involvement of women at all levels of wildlife resources management to achieve optimum resource utilization to curb poverty and famine among rural families as women are better managers and use resources at their disposal efficiently.

- Education and create awareness for farmers to understand and appreciate risks associated with climate change and variability so that they can devise appropriate community based adaptive and mitigation indigenous technologies/strategies to combat undesirable impacts of climate change.

- Farmers should be urged to grow suitable varieties that will suit the climatic conditions in their areas such as small grains which outperform maize under harsh conditions.

- Improved accessibility and availability of weather forecast information to enable farmers prepare adequately for ensuing seasons and make proper choices on more productive and viable ventures. Hence farmers should be encouraged to consult real experts on current climatic trends before venturing into any enterprise.

\section{REFERENCES}

Chasi M, Shamudzarira Z (1992). Agro-ecologies of small-scale farming areas of Zimbabwe. In: Whingwiri EE, Commercial Grain Producers' Assoclation (1983). Grain handbook. Harare, p AlC11. Cropping in the Semi- arid areas of Zimbabwe proceedings of a workshop held in Harare $24-28$ August (1987). Volume 1 and 2

Downing TE (1991) Vulnerability to hunger and coping with climate change in Africa. In: Global environmental change, Vol. 1, No. 5. Environmental 
Change Unit, University of Oxford, Oxford, p 365380.

Gukurume, S.etal. (2010). Conservation farming and the food security-insecurity matrix in Zimbabwe: A case study of ward 21 Chivi rural. Journal of Sustainable Development in Africa (Volume 12, No.7, 2010) pp 40-52.

Gukurume Simbarashe, (2014). Climate change, Variability and Sustainable Agriculture in Zimbabwe's Rural Communities, Russian Journal of Agricultural and Socio-Economic Sciences

Mahiya, I \& Gukurume, S. (forthcoming). Integrating Rights based approach in responding to effects of climate change in Chiweshe rural area. Mashingaidze K. Matanyaire CM (eds) Small scale agriculture in Zimbabwe, Book 1. Rockwood Publishers, Harare

Mutekwa, V.T. (2009). Climate change impacts and adaptation in the Agricultural sector: The case of smallholder farmers in Zimbabwe. Journal of Sustainable Development in Africa (Volume 11, No.2, 2009) pp 237-256.

Ministry of Lands, Agnculture and Water Development (MLAWD) Economics Division (1994). The agricultural sector of Zimbabwe: statistical bulletin. MLAWD, Harare

Mutasa C (2008). Evidence of climate change in Zimbabwe. Paper presented at a workshop in Kariba, Zimbabwe29-30 September, 2008.

Nyamapfene K (1991). Soils of Zimbabwe Nehanda Publishers, Harare

Rosenzweig, C. \& Parry M.L (1994). "Potential Impacts of Climate Change on World Food Security", Nature, 367.

Rosenzweig C, Parry ML (1994). Potential impact of climate change on world food supply. Nature 367.133-138

Rukuni M, Mashingaidze K, Mdtanyaire CM [eds) Small scale agriculture in Zimbabwe. Rockwood Publishers, Harare, p 7-15.

Slater, R.; Peskett, L.; Ludi, E.; \& Brown D (2007). 'Climate change, agricultural policy and poverty reduction - how much do we know?', Natural Resource Perspectives, 109.

Unganai L. S, (1996). Historic and future climate change in Zimbabwe.

Unganai S.L, (2006). Seasonal climate forecasts for farm management in Zimbabwe.

Cite this Article: Chisango FFT and Maposa A (2016). Impacts of Erotic Weather Patterns as a Result of Climate Change and Variability on Food Crop Productivity and Food Security in Zimbabwe's Arid Regions of Matabeleland; A Case of Siabuwa Communal Area in Binga District. Greener Journal of Agricultural Sciences, 6(3): 127-133, http://doi.org/10.15580/GJAS.2016.3.030316054. 